\title{
Inpatient care for patients with skin conditions in Poland - hospitalization and patient characteristics
}

\section{Opieka szpitalna nad pacjentami z chorobami skóry w Polsce - charakterystyka hospitalizacji i pacjentów}

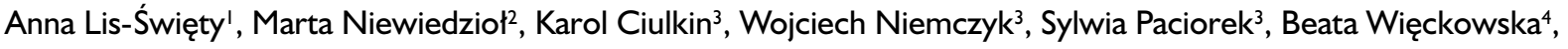 \\ Amelia Droździkowska ${ }^{3}$
}

\author{
'Department of Dermatology, School of Medicine, Medical University of Silesia, Katowice, Poland \\ 2Department of Dermatology, Venerology and Pediatric Dermatology, Medical University of Lublin, Lublin, Poland \\ ${ }^{3}$ Analyses and Strategies Department, Ministry of Health, Warsaw, Poland \\ ${ }^{4}$ Collegium of Socio-economics, SGH Warsaw School of Economics, Warsaw, Poland
}

'Klinika Dermatologii, Wydział Lekarski, Śląski Uniwersytet Medyczny w Katowicach, Polska

${ }^{2}$ Klinika Dermatologii, Wenerologii i Dermatologii Dziecięcej, Uniwersytet Medyczny w Lublinie, Polska

${ }^{3}$ Departament Analiz i Strategii, Ministerstwo Zdrowia, Warszawa, Polska

${ }^{4}$ Kolegium Ekonomiczno-Społeczne, Szkoła Główna Handlowa, Warszawa, Polska

Dermatol Rev/Przegl Dermatol 2021, 108, I-15 DOI: https://doi.org//0.5।|4/dr.2021.105888

\author{
CORRESPONDING AUTHOR/ \\ ADRES DO KORESPONDENCJI: \\ Anna Lis-Święty \\ Klinika Dermatologii \\ Wydział Lekarski \\ Śląski Uniwersytet Medyczny \\ w Katowicach \\ e-mail: alis-swiety@sum.edu.pl
}

\begin{abstract}
Introduction. Over the last few decades, an increasing proportion of skin diseases has been treated in non-dermatology wards.

Objective. Identification of the 30 most common dermatologic conditions subject to hospitalization reported by dermatologists and non-dermatologists in Poland.
\end{abstract}

Material and methods. A quantitative analysis of clinical data of the Polish National Health Fund for the year 2018 has been performed.

Results. Over 245,000 hospitalizations with regard to skin-related problems were identified, including 99,500 one-day hospitalizations. Seventy-six percent of all hospitalizations were reported in non-dermatology departments, $27 \%$ of which required a surgical procedure. Dermal infections (L03, L02, L05, A46, B08, B02) and skin tumors (D21, D23, D17, C44) were the most common reasons for hospitalization, accounting for over $30 \%$ of all hospital stays, frequently in general surgical wards. Non-dermatology wards (mostly surgical and pediatric) reported a significant proportion of emergency admissions due to cellulitis, urticaria, lower extremity ulcers, erysipelas, pressure ulcer, viral infections, and thermal and chemical burns of the trunk. Systemic connective tissue diseases were mostly treated by rheumatologists. The diseases most frequently treated by dermatologists were psoriasis $(33.5 \%$ of all admissions), dermatitis (23.8\%), malignant skin neoplasms $(12.5 \%)$, non-malignant skin neoplasms $(10.5 \%)$ and lower extremity ulcers (L97) $(10.5 \%)$. Patients in dermatology wards were older than those in non-dermatology ones (52.3 years versus 42.8 years respectively, $p<0.001$ ). The average length of stay (ALOS) was 5.1 days, but patients in dermatology wards stayed longer $(p<0.001)$.

Conclusions. A higher number of dermatosurgeons and dermatologists as hospital consultants might help ensure better use of inpatient facilities. 


\section{STRESZCZENIE}

Wprowadzenie. W ostatnich kilkudziesięciu latach coraz większy odsetek chorób skóry jest leczony na oddziałach niedermatologicznych.

Cel. Ustalenie 30 najczęstszych chorób skóry będących przyczyną hospitalizacji zgłaszanych przez dermatologów i niedermatologów w Polsce.

Materiał i metody. Przeprowadzono analizę ilościową danych klinicznych Narodowego Funduszu Zdrowia za rok 2018.

Wyniki. Stwierdzono ponad 245000 hospitalizacji z powodu chorób skóry, z czego ponad 99500 było hospitalizacjami jednodniowymi. Siedemdziesiąt sześć procent wszystkich tych hospitalizacji odbywało się na oddziałach niedermatologicznych, przy wynoszącym $27 \%$ odsetku zabiegów chirurgicznych. Najczęstszą przyczyną hospitalizacji - często na oddziałach chirurgii ogólnej - były zakażenia (L03, L02, L05, A46, B08, B02) i nowotwory skóry (D21, D23, D17, C44), co stanowi łącznie ponad $30 \%$ wszystkich hospitalizacji. Oddziały niedermatologiczne (w większości przypadków chirurgiczne i pediatryczne) raportowały znaczny odsetek przyjęć pilnych z powodu zapalenia tkanki łącznej, pokrzywki, owrzodzeń kończyn dolnych, róży, odleżyn, zakażeń wirusowych, oparzeń termicznych i chemicznych tułowia. Układowe choroby tkanki łącznej w większości przypadków były leczone przez reumatologów. Chorobami najczęściej leczonymi przez dermatologów były łuszczyca (33,5\% wszystkich hospitalizacji), zapalenie skóry $(23,8 \%)$, nowotwory złośliwe skóry $(12,5 \%)$ i niezłośliwe $(10,5 \%)$ oraz owrzodzenia kończyn dolnych (L97) (10,5\%). Pacjenci leczeni na oddziałach dermatologicznych byli starsi od pacjentów leczonych na oddziałach niedermatologicznych (odpowiednio 52,3 i 42,8 roku, $p<0,001$ ). Średni czas hospitalizacji wynosił 5,1 dnia, przy czym w przypadku pacjentów leczonych na oddziałach dermatologicznych był on dłuższy $(p<0,001)$.

Wnioski. Zwiększenie liczby dermatochirurgów i dermatologów pełniących funkcję konsultantów szpitalnych mogłoby wpłynąć na lepsze wykorzystywanie zasobów szpitalnych.

Key words: epidemiology, dermatology, inpatient care.

Słowa kluczowe: epidemiologia, dermatologia, opieka szpitalna.

\section{INTRODUCTION}

About $20 \%$ of the general population suffer from skin diseases, the treatment of which is mainly provided in outpatient facilities. Nonetheless, some patients with more complicated or severe skin diseases require admission to hospital. The relative frequency of different skin diseases requiring inpatient care may vary in different geographic regions [1-8]. Recent studies on inpatient dermatology mainly come from tertiary referral hospitals in Australia, Brazil, Lebanon, Eastern India and Nepal [1-5]. There are only a few studies that have been published in European countries, none of which relates to the last decade [9-12]. Advances in therapeutic modalities, improved outpatient services and different endpoints for discharge have considerably changed the trends in dermatology care. The United States and the United Kingdom have reported a reduction in the

\section{WPROWADZENIE}

Choroby skóry dotyczą ok. 20\% populacji ogólnej, a ich leczenie odbywa się głównie w warunkach ambulatoryjnych. Niektórzy pacjenci z bardziej złożonymi lub ciężkimi schorzeniami skóry wymagają jednak hospitalizacji. Względna częstość występowania różnych chorób skóry wymagających opieki szpitalnej różni się w zależności od regionu geograficznego [1-8]. Najnowsze badania dotyczące szpitalnego leczenia dermatologicznego pochodzą głównie ze szpitali o III stopniu referencyjności w Australii, Brazylii, Libanie, wschodnich Indiach i Nepalu [1-5]. Niewiele jest publikacji poświęconych krajom europejskim, a żadne z tych opracowań nie odnosi się do ostatniej dekady [9-12]. Postępy w metodach leczenia, wyższa jakość świadczeń ambulatoryjnych oraz różne punkty końcowe wypisu ze szpitala znacząco zmieniły trendy w opiece dermatologicznej. W Stanach Zjednoczonych 
number of institutions with dedicated dermatology beds [9, 13-15]. Although dermatologists continue to provide consultative services for hospitalized patients, many academic dermatology centers across the United States no longer provide primary hospital care [16]. Over the last few decades, an increasing proportion of skin diseases have come to be managed by non-dermatologists. Several studies point out the inadequacies of knowledge in relation to dermatological conditions among non-dermatologists [17-22]. Dermatologic inpatient care may be inadequately and inefficiently provided by non-dermatologists, with a report of up to a $77 \%$ rate of misdiagnosis and a potential consequent change of management [17, 19, 20, 23-27]. According to some authors, a correct provisional diagnosis by the referring specialty was most common in cases of infectious diseases, such as cellulitis, tinea pedis, and herpes labialis [18]. In Central Europe and Germany, dermatology has a long tradition as an individual and broad-spectrum field in medicine, with its main focus placed on inpatient care [12]. However, data about inpatient dermatology in this region are not well described.

\section{OBJECTIVE}

The purpose of this study was to identify the 30 most common dermatologic conditions subject to hospitalization and compare those reported by dermatologists versus those reported by non-dermatologists (i.e. internists, pediatricians, rheumatologists, general surgeons, etc.) in Poland. With this knowledge, the authors hope that the assessment of health care needs can be modified to reflect the current epidemiology of cutaneous diseases, thereby improving patient care.

\section{MATERIAL AND METHODS}

The research was conducted based on data of the Polish National Health Fund (NHF) on hospital health care services in 2018. The database contains information on all medical procedures reported to and gathered by the NHF as well as other data on hospitalizations reported to acquire financing for the treatment. Therefore, data covered all skin-related hospitalizations in Polish public health care facilities.

The first step in gathering data used in this paper was to separate all ICD-10 codes that were reported by any dermatology department in 2018 as the main problem treated. Next, the database query was performed concerning all hospitalizations which had those problems or diseases reported as the main reason for hospitalization, regardless of the department. In effect, the skin-related data contained information i Wielkiej Brytanii stwierdzono zmniejszenie liczby placówek z wyznaczonymi łóżkami dermatologicznymi [9, 13-15]. Mimo że dermatolodzy nadal pełnią funkcję konsultantów dla hospitalizowanych pacjentów, w Stanach Zjednoczonych wiele klinicznych ośrodków dermatologicznych nie udziela już świadczeń z zakresu opieki szpitalnej [16]. W ostatnich kilku dziesięcioleciach coraz większy odsetek chorób skóry jest leczony przez lekarzy innych specjalności niż dermatolodzy. Kilka dostępnych badań wskazuje na braki w wiedzy na temat schorzeń dermatologicznych wśród lekarzy innych specjalności [17-22]. W przypadku tych lekarzy istnieje ryzyko, że opieka szpitalna nad pacjentami dermatologicznymi będzie niewystarczająca i nieskuteczna, na co może wskazywać wysoki odsetek (nawet $77 \%$ ) błędnych rozpoznań i związanych z tym modyfikacji leczenia $[17,19,20,23-27]$. Według niektórych autorów prawidłowe wstępne rozpoznanie ustalone przez kierującego lekarza dotyczyło najczęściej chorób infekcyjnych, takich jak zapalenie tkanki łącznej, grzybica stóp i opryszczka wargowa [18]. W Europie Środkowej i Niemczech dermatologia ma długą tradycję jako odrębna dziedzina medycyny o szerokim spektrum świadczonych usług, skupiająca się głównie na opiece szpitalnej [12]. Jednocześnie brakuje szczegółowych danych opisujących funkcjonowanie dermatologii szpitalnej $w$ tym regionie.

\section{CEL}

Celem badania było ustalenie 30 najczęstszych chorób skóry będących przyczyną hospitalizacji i porównanie schorzeń zgłaszanych przez lekarzy dermatologów i lekarzy innych specjalności (tj. internistów, pediatrów, reumatologów, chirurgów ogólnych itp.) w Polsce. Autorzy pracy mają nadzieję, że zdobyta w ten sposób wiedza umożliwi zmodyfikowaną ocenę potrzeb zdrowotnych, aby odzwierciedlić aktualną epidemiologię chorób skóry, co przełoży się na poprawę jakości opieki nad pacjentami.

\section{MATERIAŁ I METODY}

Badanie przeprowadzono na podstawie danych Narodowego Funduszu Zdrowia (NFZ) dotyczących świadczeń szpitalnych w 2018 roku. Baza zawiera informacje o wszystkich procedurach medycznych zgłaszanych do NFZ, a także inne dane o hospitalizacjach raportowane w celu pozyskania funduszy na leczenie. W związku z tym analiza objęła wszystkie hospitalizacje związane $\mathrm{z}$ chorobami skóry w polskich publicznych zakładach opieki zdrowotnej.

Pierwszym krokiem w procesie gromadzenia danych na potrzeby niniejszej pracy była selekcja kodów ICD-10, które zostały zgłoszone przez oddziały 
on over 245,000 hospitalizations (regular and oneday-long).

Taking into consideration that data on all skin-related hospitalizations that had been conducted in Poland were collected, statistical tests were not required in most cases. However, the tests were performed when it was necessary to determine whether a part of the population came from a different data generating process. This was the case with regard to the length of stay compared between individual wards.

When comparing the average duration of hospitalization, it was assumed that a minimum length of stay was one day. During the first step of the analysis of the length of hospital stay, the Kruskal-Wallis rank sum test on all data was performed. Based on the calculated value of the test statistic, it could be assumed that the alternative hypothesis was true $(p<0.01)$ - there were differences between wards. To find out which wards caused the differences, Dunn's test was conducted. The only pair of ward groups that had insignificant differences were surgical and other ones. As a result of using the Wilcoxon rank sum test to determine the conditions that were subject to different lengths of hospital stay at a dermatology ward compared to all other departments, as many as 23 ICD-10 codes were identified as statistically significant

The aim of the next step was to determine which skin conditions were treated differently in dermatology wards. For this purpose, all non-dermatologic wards were combined into one group of wards, and the sample was narrowed down to ICD-10 codes subject to more than 40 hospitalizations. Next, for each of those diseases, the Wilcoxon rank sum test was conducted, in order to group the hospitalizations by the ward in which the patients were treated.

When considering readmissions at the level of ICD-10 codes, the analysis was narrowed down to conditions that resulted in a minimum of 500 hospitalizations and a minimal rate of readmissions of $2 \%$. This step was considered necessary because the variation associated with a low number of observations could make the analysis less relevant and potentially biased.

To acquire more insight into the surgical data, the surgical wards were divided into the following categories, based on their specialization code: pediatric, general, oncological and plastic surgery including dermatology wards. All other wards fell into the 'other' category for the purpose of this part of the analysis.

All the tables included in the study present the 30 most common skin-related ICD-10 codes reported to the NHF in 2018. dermatologiczne w 2018 roku jako główne rozpoznania u hospitalizowanych pacjentów. Następnie wykonano kwerendę bazy danych dotyczącą wszystkich hospitalizacji, w których te choroby lub zaburzenia zostały podane jako główna przyczyna przyjęcia, niezależnie od oddziału. W rezultacie zgromadzono informacje dermatologiczne dotyczące ponad 245000 hospitalizacji (zwykłych i jednodniowych).

Zebrane dane dotyczyły wszystkich hospitalizacji z przyczyn chorób skóry w Polsce, dlatego w większości przypadków nie były wymagane analizy statystyczne. Przeprowadzano je wówczas, gdy konieczne było ustalenie, czy część populacji pochodzi z innego procesu generowania danych. Dotyczyło to na przykład porównywania czasu pobytu na poszczególnych oddziałach.

Porównując średnie okresy hospitalizacji, przyjęto, że minimalna długość pobytu w szpitalu wynosiła jeden dzień. W pierwszym etapie analizy długości hospitalizacji wykonano test sumy rang Kruskala-Wallisa w całym zbiorze danych. Na podstawie obliczonej wartości statystycznej można było uznać, że prawdziwa jest hipoteza alternatywna $(p<0,01)$ - występowały różnice między oddziałami. Aby ustalić, które oddziały odpowiadały za te różnice, wykonano test Dunna. Jedyną parą grup oddziałów, w której stwierdzono nieznamienne różnice, były oddziały chirurgiczne i inne. Po zastosowaniu testu sumy rang Wilcoxona w celu ustalenia, które schorzenia odpowiadają za zróżnicowaną długość hospitalizacji na oddziałach dermatologicznych w porównaniu z wszystkimi pozostałymi oddziałami, aż 23 kody ICD-10 zostały zidentyfikowane jako znamienne statystycznie.

Celem kolejnego etapu było określenie, które schorzenia skóry są inaczej leczone na oddziałach dermatologii niż na pozostałych. W tym celu wszystkie oddziały niedermatologiczne połączono w jedną grupę, a próbę ograniczono do kodów ICD-10, których dotyczyło więcej niż 40 hospitalizacji. W następnym kroku dla każdej z chorób wykonano test sumy rang Wilcoxona w celu pogrupowania hospitalizacji według oddziału, na którym byli leczeni pacjenci.

Rozważając ponowne hospitalizacje na poziomie kodów ICD-10, analizę zawężono do schorzeń, które powodowały co najmniej 500 hospitalizacji i minimalny odsetek ponownych przyjęć wynoszący $2 \%$. Etap ten uznano za niezbędny, ponieważ zmienność związana z niewielką liczbą obserwacji mogłaby obniżyć znamienność analizy i potencjalnie doprowadzić do błędu systematycznego.

W celu uzyskania lepszego wglądu w dane chirurgiczne oddziały chirurgii podzielono na kilka kategorii w zależności od kodu specjalizacji: chirurgia dziecięca, ogólna, onkologiczna i plastyczna, odddziały dermatologiczne. Na potrzeby tej części analizy wszystkie pozostałe oddziały zostały zaliczone do kategorii „inne”.

We wszystkich tabelach zawartych w pracy zestawiono 30 najczęściej występujących kodów ICD-10 


\section{RESULTS}

Skin conditions accounted for more than 245,000 hospitalizations in Polish public health care facilities. Infections (L03, L02, L05, A46, B08, B02 - 15.9\%), and skin tumors (D21, D23, D17, C44) were the most common reasons for hospitalization, constituting over $14.3 \%$ of all admissions. They were followed by dermatitis (L20, L23, L27, L30 - 8.3\%), psoriasis (L40) $(8.2 \%)$, urticaria (L50 - 6.1\%) and lower extremity ulcers (L97 - 5.5\%). Only $24 \%$ of all hospital stays were reported in dermatology and venereology wards. The non-dermatology wards were mostly surgical $(27 \%$ of all admissions), rheumatology (9.6\%), internal medicine $(6.7 \%)$ and pediatric $(5 \%)$ wards. Table 1 contains data on the number of hospitalizations by ICD-10 code and ward type. Dermatologists mostly treated psoriasis L40 (35.6\% of all hospitalizations in this ward), dermatitis (L20, L27, L23, L30 - 23.8\%) and lower extremity ulcers (L97 - 10.5\%).

Emergency admissions accounted for $44.1 \%$ of all hospitalizations under analysis, and $86.5 \%$ of all emergency hospitalizations under analysis were reported in non-dermatology departments. Cellulitis and acute lymphangitis (L03) was the most frequent cause of emergency admissions $(14,400 ; 79.53 \%$ of all L03 hospitalizations). It was followed by urticaria (L50 - 7,500; 81.66\%) and chronic ulcers of the lower limb (L97 - 7,000; 59.17\%). Percentages of emergency hospitalizations by ICD-10 code and ward type are shown in table 2 . With regard to the dermatology wards, psoriasis (L40) was the main reason for emergency hospitalizations $(2,900 ; 17.4 \%$ of all L40 hospitalizations in the dermatology wards). The subsequent most urgent ICD-10 codes were chronic ulcers of the lower limb (L97 - 2,100; 36.3\%) and dermatitis due to internally administered substances (L27 - 1,$600 ; 55.9 \%)$. Analogous codes for surgical wards were cellulitis and acute lymphangitis (L03 - 13,700; $73.4 \%$ ), chronic ulcers of the lower limb (L97 - 3,200; $62.6 \%)$ and other local infections of the skin and subcutaneous tissue (L08 - 3,000; 28.7\%).

As many as $35.42 \%$ of all hospitalizations in the analysis were surgical. When narrowed down to dermatology departments, this statistic was $4.73 \%$, compared to $95.3 \%$ in all other departments (a total of $100 \%$, departments broken down into dermatological and all other units, i.e. all departments are covered). The number of surgical hospitalizations and their share by ICD-10 code and ward type are provided in table 3. It is worth noting that this table contains information only about the ICD-10 codes that had a significant share of surgical hospitalizations. Surgeons mostly dealt with skin tumors (D21, D23, D17, C44) (44\% of all hospitalizations in this ward type) and dotyczących chorób skóry zgłoszonych do NFZ w 2018 roku.

\section{WYNIKI}

Choroby skóry stanowiły przyczynę ponad 245000 hospitalizacji w polskich publicznych zakładach opieki zdrowotnej. Najczęstszymi przyczynami hospitalizacji (ponad 14,3\% wszystkich przyjęć szpitalnych) były zakażenia (L03, L02, L05, A46, B08, B02) i nowotwory skóry (D21, D23, D17, C44). Kolejne przyczyny według częstości występowania to: zapalenie skóry (L20, L23, L27, L30 - 8,3\%), łuszczyca (L40 -8,2\%), pokrzywka (L50 - 6,1\%) i owrzodzenie kończyn dolnych (L97 $5,5 \%)$. Zaledwie $24 \%$ wszystkich pobytów w szpitalu zgłoszono na oddziałach dermatologii i wenerologii. Wśród oddziałów niedermatologicznych były przede wszystkim oddziały chirurgiczne (27\% wszystkich przyjęć), reumatologiczne $(9,6 \%)$, internistyczne $(6,7 \%)$ i pediatryczne (5\%). Dane o liczbie hospitalizacji według kodu ICD-10 i typu oddziału zestawiono w tabeli 1. Dermatolodzy leczyli głównie łuszczycę L40 (35,6\% wszystkich hospitalizacji na oddziałach tego typu), zapalenie skóry (L20, L27, L23, L30 - 23,8\%) oraz owrzodzenia kończyn dolnych (L97 - 10,5\%).

Przyjęcia w trybie pilnym stanowiły $44,1 \%$ wszystkich objętych analizą hospitalizacji, przy czym 86,5\% analizowanych pobytów szpitalnych w przypadkach pilnych dotyczyło oddziałów innych niż dermatologiczne. Najczęstszymi przyczynami przyjęć w trybie pilnym (14 400; 79,53\% wszystkich hospitalizacji z kodem L03) były zapalenie tkanki łącznej i ostre zapalenie naczyń chłonnych (L03). Dalej w kolejności znalazły się pokrzywka (L50 - 7500; 81,66\%) i przewlekłe owrzodzenie kończyny dolnej (L97 - 7000; 59,17\%). Odsetki hospitalizacji w przypadkach pilnych według kodu ICD-10 i typu oddziału przedstawiono w tabeli 2. Łuszczyca (L40) była podstawową przyczyną hospitalizacji w trybie pilnym na oddziałach dermatologicznych (2900; 17,4\% wszystkich hospitalizacji z kodem L40 na tych oddziałach). Następne w kolejności schorzenia wymagające pilnej hospitalizacji (według kodów ICD-10) to: przewlekłe owrzodzenie kończyny dolnej (L97 - 2100; 36,3\%) oraz zapalenie skóry wywołane przez substancje wprowadzone do organizmu (L27 - 1600; 55,9\%). Analogiczne kody dla oddziałów chirurgicznych obejmowały: zapalenie tkanki łącznej i ostre zapalenie naczyń chłonnych (L03 - 13 700; 73,4\%), przewlekłe owrzodzenie kończyny dolnej (L97 - 3200; 62,6\%) oraz inne miejscowe zakażenia skóry i tkanki podskórnej (L08) $(3000 ; 28,7 \%)$.

$35,42 \%$ wszystkich hospitalizacji objętych analizą miało charakter chirurgiczny. Po zawężeniu do oddziałów dermatologicznych odsetek ten wyniósł 4,73\%, w porównaniu z 95,3\% we wszystkich pozostałych oddziałach (łącznie 100\%; oddziały podzielono na dermatologiczne i pozostałe, czyli wszystkie zostały uwzględ- 
Table I. Number of hospitalizations (in thousands) by ICD- 10 code and ward type

Tabela I. Liczba hospitalizacji (w tys.) dla poszczególnych kodów ICD- 10 i typów oddziałów

\begin{tabular}{|c|c|c|c|c|c|c|c|c|c|c|c|c|c|c|c|c|c|c|}
\hline \multirow[b]{2}{*}{ 음 } & \multicolumn{3}{|c|}{$\begin{array}{l}\text { Dermatology/ } \\
\text { Dermatologia }\end{array}$} & \multicolumn{3}{|c|}{ Surgical/Chirurgia } & \multicolumn{3}{|c|}{$\begin{array}{l}\text { Rheumatology/ } \\
\text { Reumatologia }\end{array}$} & \multicolumn{3}{|c|}{$\begin{array}{c}\text { Internal medicine/ } \\
\text { Medycyna wewnętrzna }\end{array}$} & \multicolumn{3}{|c|}{ Pediatric/Pediatria } & \multicolumn{3}{|c|}{ Other/Inne } \\
\hline & 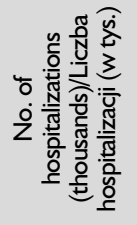 & ㅇํㅇ & $\stackrel{*}{*}$ & 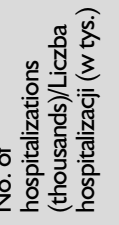 & $\stackrel{*}{\circ}$ & 䊑 & 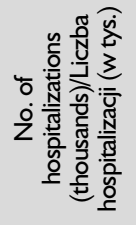 & $\stackrel{*}{\circ}$ & $\stackrel{*}{*}$ & 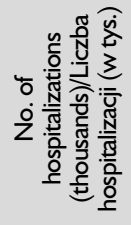 & 。ํ & $\stackrel{*}{*}$ & 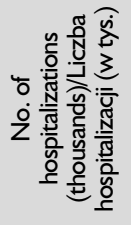 & 웅 & $\stackrel{*}{*}$ & 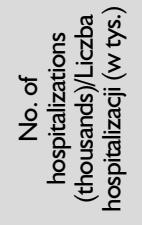 & 类 & 类 \\
\hline L03 & 0.2 & 0.8 & 0.4 & 15.6 & 68.7 & 27.5 & - & - & - & 0.2 & I & 1.6 & 0.1 & 0.5 & 1.2 & 6.5 & 28.9 & 9.9 \\
\hline L40 & 14.9 & 74.3 & 35.6 & - & - & - & 4.2 & 21 & 21 & 0.2 & 1.1 & 1.6 & 0 & 0.1 & 0.1 & 0.7 & 3.4 & I \\
\hline L50 & 2.1 & 13.7 & 4.9 & - & - & - & 0 & 0.1 & 0.1 & 1.8 & 11.7 & 12.5 & 4.7 & 31.1 & 44.2 & 6.5 & 43.3 & 9.8 \\
\hline D23 & 1.6 & 11.1 & 3.7 & 8.2 & 59 & 14.6 & - & - & - & - & - & - & - & - & - & 4.2 & 29.8 & 6.3 \\
\hline L97 & 4.4 & 32.5 & 10.5 & 4.9 & 36.2 & 8.7 & - & - & - & 1.2 & 8.9 & 8.5 & - & - & - & 3 & 22.4 & 4.6 \\
\hline C44 & 2.3 & 19.8 & 5.5 & 7 & 59.1 & 12.3 & - & - & - & 0 & 0.1 & 0.1 & - & - & - & 2.5 & 21 & 3.7 \\
\hline M35 & 0.3 & 2.6 & 0.7 & 0 & 0.2 & 0 & 7.7 & 69 & 38.4 & 1.7 & 14.9 & 11.9 & 0.5 & 4.7 & 5 & I & 8.7 & 1.5 \\
\hline L98 & 1 & 10.9 & 2.4 & 5 & 55.1 & 8.8 & 0 & 0.1 & 0 & 0.2 & 1.7 & 1.1 & 0.4 & 4.2 & 3.6 & 2.6 & 28.1 & 3.9 \\
\hline L89 & 0.1 & 0.7 & 0.1 & 1.2 & 14.6 & 2.1 & - & - & - & 2.3 & 28.1 & 16.2 & 0 & 0 & 0 & 4.6 & 56.6 & 6.9 \\
\hline A46 & 1.3 & 18.6 & 3.1 & 0.2 & 2.9 & 0.4 & - & - & - & 0.4 & 5.6 & 2.8 & 0 & 0.4 & 0.3 & 5 & 72.3 & 7.6 \\
\hline L08 & 0.2 & 3.4 & 0.6 & 1.3 & 19.3 & 2.3 & - & - & - & 0.1 & 1.1 & 0.5 & 0.3 & 4.3 & 2.8 & 4.9 & 71.9 & 7.4 \\
\hline L20 & 2 & 31.7 & 4.7 & - & - & - & - & - & - & 1.8 & 28.9 & 12.9 & 1.6 & 25.8 & 15.4 & 0.9 & 13.6 & 1.3 \\
\hline D21 & 0 & 0.1 & 0 & 5 & 81.2 & 8.8 & - & - & - & 0 & 0.1 & 0.0 & - & - & - & 1.1 & 18.6 & 1.7 \\
\hline R22 & 0 & 0.2 & 0 & 0.6 & 9.5 & 1 & - & - & - & 0 & 0.6 & 0.3 & 0.1 & 1.1 & 0.6 & 5.3 & 88.5 & 7.9 \\
\hline L02 & 0 & 0.1 & 0 & 1.7 & 29.7 & 3 & - & - & - & 0 & 0.1 & 0 & 0 & 0.1 & 0 & 4 & 70.1 & 6 \\
\hline L30 & 3.1 & 58.6 & 7.3 & 0.1 & 2 & 0.2 & - & - & - & 0.3 & 5.2 & 1.9 & 0.1 & 1.4 & 0.7 & 1.7 & 32.7 & 2.6 \\
\hline L27 & 2.2 & 44.3 & 5.3 & 0 & 0.1 & 0 & - & - & - & 1 & 20.8 & 7.4 & 0.5 & 9.1 & 4.3 & 1.3 & 25.6 & 1.9 \\
\hline M32 & 0.3 & 7.2 & 0.8 & 0 & 0.2 & 0 & 3.0 & 64.3 & 15.1 & 0.5 & 9.6 & 3.2 & 0.2 & 3.2 & 1.4 & 0.7 & 15.5 & 1.1 \\
\hline M3I & 0.2 & 5.5 & 0.5 & 0 & 0.2 & 0 & 1.7 & 40.6 & 8.3 & 0.7 & 16.0 & 4.7 & 0.1 & 3.3 & 1.3 & 1.4 & 34.4 & 2.1 \\
\hline L23 & 2.7 & 72.2 & 6.4 & 0 & 0.2 & 0 & 0 & 0.1 & 0 & 0.3 & 6.9 & 1.8 & 0 & 0.4 & 0.2 & 0.8 & 20.2 & 1.1 \\
\hline M34 & 0.8 & 24.5 & 1.9 & 0 & 0.1 & 0 & 2.1 & 64.5 & 10.3 & 0.2 & 6.2 & 1.4 & 0 & 1.2 & 0.4 & 0.1 & 3.5 & 0.2 \\
\hline DI7 & 0 & 0.3 & 0 & 2.9 & 95 & 5.2 & - & - & - & 0 & 0.1 & 0 & 0 & 0 & 0 & 0.1 & 4.6 & 0.2 \\
\hline L60 & 0 & 1.4 & 0.1 & 1.6 & 54.7 & 2.8 & - & - & - & 0 & 0.0 & 0 & 0 & 0.1 & 0 & 1.3 & 43.7 & 1.9 \\
\hline T78 & 0.2 & 6.8 & 0.5 & 0 & 0.1 & 0 & 0 & 0.1 & 0 & 1 & 35.4 & 7.1 & 0.5 & 16.6 & 4.4 & 1.1 & 40.9 & 1.7 \\
\hline $\mathrm{BO2}$ & 0.3 & 13.8 & 0.8 & 0 & 0.5 & 0 & - & - & - & 0.1 & 3.6 & 0.6 & 0 & 0.9 & 0.2 & 2 & 81.2 & 3 \\
\hline 183 & 0.1 & 6.7 & 0.3 & 1.2 & 56.8 & 2.1 & - & - & - & 0 & 1.4 & 0.2 & - & - & - & 0.7 & 35.1 & 1.1 \\
\hline L94 & 1.2 & 66.1 & 2.9 & 0 & 2.5 & 0.1 & 0.2 & 12.6 & 1.1 & 0 & 0.9 & 0.1 & 0.2 & 12.9 & 2.2 & 0.1 & 4.9 & 0.1 \\
\hline BOI & 0 & 0.5 & 0 & 0 & 0.2 & 0 & - & - & - & 0 & 0.1 & 0 & 0.2 & 9.7 & 1.6 & 1.6 & 89.5 & 2.4 \\
\hline M33 & 0.1 & 8.2 & 0.3 & 0 & 0.8 & 0 & 1.1 & 61.6 & 5.3 & 0.1 & 6.8 & 0.8 & 0.1 & 6.5 & 1.1 & 0.3 & 16.1 & 0.4 \\
\hline D69 & 0.2 & 14.8 & 0.6 & 0 & 0.2 & 0 & 0 & 1.9 & 0.2 & 0.1 & 4.6 & 0.5 & 0.9 & 57 & 8.9 & 0.4 & 21.4 & 0.5 \\
\hline
\end{tabular}

The numbers are corrected to one decimal place. This means that ' 0 ' in the column 'No. of hospitalizations (thousands)' means fewer than 50 hospitalizations. '- ' means zero hospitalizations/Liczby sq zaokrqgglone do jednego miejsca po przecinku. Zatem „0” w kolumnie „Liczba hospitalizacji (w tys.)” oznacza mniej niż 50 hospitalizacji, a „-" oznacza zero hospitalizacji.

*No. of hospitalizations in the ward due to the condition/Total number of hospitalizations due to the condition. **No. of hospitalizations in the ward due to the condition/Total number of hospitalizations in the ward./*Liczba hospitalizacji na oddziale z powodu choroby/tączna liczba hospitalizacji z powodu choroby.

***iczba hospitalizacji na oddziale z powodu choroby/tączna liczba hospitalizacji na oddziale. 
Table 2. Number of emergency admissions (corrected to hundreds) and their share in total hospitalizations by ICD-I0 code and ward type Tabela 2. Liczba hospitalizacji w trybie pilnym (zaokrąglona do stu) i ich udział procentowy we wszystkich hospitalizacjach dla poszczególnych kodów ICD- 10 i typów oddziałów

\begin{tabular}{|c|c|c|c|c|c|c|c|c|c|c|c|c|}
\hline \multirow[t]{2}{*}{ ICD-10 } & \multicolumn{2}{|c|}{$\begin{array}{l}\text { Dermatology/ } \\
\text { Dermatologia }\end{array}$} & \multicolumn{2}{|c|}{$\begin{array}{l}\text { Rheumatology/ } \\
\text { Reumatologia }\end{array}$} & \multicolumn{2}{|c|}{ Surgical/Chirurgia } & \multicolumn{2}{|c|}{$\begin{array}{c}\text { Internal medicine/ } \\
\text { Medycyna } \\
\text { wewnętrzna }\end{array}$} & \multicolumn{2}{|c|}{ Pediatric/Pediatria } & \multicolumn{2}{|c|}{ Other/Inne } \\
\hline & No./Liczba & \%* & No./Liczba & \%* & No./Liczba & \%* & No./Liczba & \%* & No./Liczba & \%* & No./Liczba & \%* \\
\hline L03 & 74 & 39.8 & 4 & 44.4 & 11429 & 73.4 & 200 & 88.5 & 101 & 81.5 & 6257 & 95.7 \\
\hline L40 & 2591 & 17.4 & 180 & 4.3 & I & 11.1 & 58 & 25.4 & 5 & 38.5 & 471 & 69.3 \\
\hline L50 & 911 & 44.3 & 7 & 58.3 & 4 & 66.7 & 968 & 55.1 & 4073 & 87.3 & 6288 & 96.9 \\
\hline D23 & 99 & 6.4 & 0 & 0 & 1135 & 13.8 & 2 & 66.7 & 1 & 33.3 & 237 & 5.7 \\
\hline L97 & 1601 & 36.3 & 5 & 83.3 & 3077 & 62.6 & 860 & 71.5 & 0 & - & 2517 & 82.7 \\
\hline C44 & 65 & 2.8 & 0 & 0 & 386 & 5.6 & 10 & 90.9 & 0 & - & 205 & 8.3 \\
\hline M35 & 10 & 3.5 & 725 & 9.4 & 0 & 0 & 439 & 26.3 & 129 & 24.6 & 346 & 35.6 \\
\hline L98 & 204 & 20.7 & I & 11.1 & 1438 & 28.7 & 121 & 77.6 & 338 & 88.9 & 1010 & 39.6 \\
\hline L89 & 29 & 52.7 & 3 & 75 & 822 & 69.7 & 2098 & 92.1 & 0 & 0 & 1082 & 23.6 \\
\hline A46 & 997 & 77.2 & 2 & 66.7 & 174 & 85.7 & 364 & 93.1 & 26 & 89.7 & 3616 & 72.1 \\
\hline L08 & 145 & 62.0 & 0 & 0 & 989 & 75.0 & 69 & 94.5 & 263 & 90.1 & 4809 & 97.9 \\
\hline L20 & 600 & 30.1 & 0 & 0 & I & 33.3 & 143 & 7.9 & 698 & 43.1 & 706 & 82.3 \\
\hline D21 & 0 & - & 0 & 0 & 571 & 11.4 & 3 & 60 & 1 & 33.3 & 53 & 4.6 \\
\hline R22 & 1 & 7.7 & 1 & 50 & 30 & 5.3 & 27 & 73 & 58 & 86.6 & 2600 & 49.5 \\
\hline L02 & 2 & 50 & 0 & - & 1283 & 76.3 & 2 & 50 & 2 & 50 & 3829 & 96.5 \\
\hline L30 & 986 & 32 & 1 & 50 & 60 & 57.7 & 171 & 62.6 & 66 & 86.8 & 1640 & 95.6 \\
\hline L27 & 1248 & 55.9 & 1 & 50 & 2 & 40 & 262 & 25 & 269 & 58.7 & 1091 & 84.5 \\
\hline M32 & 46 & 13.5 & 269 & 8.8 & 3 & 37.5 & 156 & 34.4 & 51 & 33.3 & 180 & 24.5 \\
\hline M3I & 90 & 39.6 & 198 & 11.8 & 1 & 12.5 & 167 & 25.3 & 108 & 78.3 & 312 & 21.9 \\
\hline L23 & 640 & 23.9 & 1 & 50 & 6 & 66.7 & 80 & 31.4 & 10 & 62.5 & 694 & 92.5 \\
\hline M34 & 12 & 1.5 & 108 & 5.2 & 2 & 50 & 35 & 17.7 & 5 & 12.8 & 35 & 31.5 \\
\hline DI7 & 0 & - & 0 & 0 & 306 & 10.4 & 1 & 50 & 0 & - & 94 & 65.3 \\
\hline L60 & 6 & 14.3 & 0 & 0 & 235 & 14.8 & 0 & - & 1 & 50 & 1168 & 92 \\
\hline T78 & 113 & 59.5 & 1 & 50 & 2 & 66.7 & 506 & 51 & 409 & 87.8 & 799 & 69.7 \\
\hline B02 & 272 & 79.1 & 0 & - & 10 & 76.9 & 75 & 84.3 & 20 & 90.9 & 1899 & 94.1 \\
\hline 183 & 25 & 18 & 0 & 0 & 434 & 36.9 & 23 & 79.3 & 0 & - & 665 & 91.5 \\
\hline L94 & 78 & 6.5 & 6 & 2.6 & 19 & 41.3 & 9 & 52.9 & 45 & 19.2 & 48 & 54.5 \\
\hline BOI & 6 & 66.7 & 0 & - & 2 & 66.7 & 1 & 50 & 158 & 91.3 & 1525 & 95.7 \\
\hline M33 & 13 & 9.2 & 107 & 10.1 & 7 & 53.8 & 41 & 35 & 27 & 24.1 & 60 & 21.7 \\
\hline D69 & 145 & 59.4 & 24 & 75 & I & 25 & 62 & 81.6 & 852 & 90.7 & 297 & 84.4 \\
\hline
\end{tabular}

'- 'means no hospitalizations. '0' means less than 50 hospitalizations./,-" oznacza brak hospitalizacji. „0” oznacza mniej niż 50 hospitalizacji.

*No. of emergency hospitalizations in the ward/Total number of hospitalizations in the ward/*Liczba hospitalizacji w trybie pilnym na oddziale/tączna liczba hospitalizacji na oddziale.

cellulitis $(14 \%)$. Almost half of the hospitalizations in these wards were one-day stays $(40.7 \%)$.

Patients treated in dermatology wards were older than in non-dermatology units (52.3 years vs. 42.8 years respectively, $p<0.001$ ). The average length of stay (ALOS) was 5.1 days, which was longer for patients in non-dermatology wards $(p<0.001)$. Table 4 shows nione). Liczbę hospitalizacji chirurgicznych i ich udział według kodu ICD-10 i typu oddziału przedstawiono w tabeli 3. Należy podkreślić, że tabela zawiera dane wyłącznie o kodach ICD-10, które miały istotny udział w hospitalizacjach chirurgicznych. Chirurdzy zajmowali się najczęściej nowotworami skóry (D21, D23, D17, C44) (44\% wszystkich hospitalizacji na oddzia- 
Table 3. Number and percentage share of surgical hospitalizations by ICD- 10 code, totals and by ward type (figures corrected to hundreds) Tabela 3. Liczba i udział procentowy hospitalizacji chirurgicznych dla poszczególnych kodów ICD- I0, łącznie i w podziale na poszczególne typy oddziałów (wartości zaokrąglono do stu)

\begin{tabular}{|c|c|c|c|c|c|c|c|c|c|c|c|c|c|c|}
\hline \multirow[t]{2}{*}{$\begin{array}{l}\text { ICD- } \\
10\end{array}$} & \multicolumn{2}{|c|}{ Total/Łącznie } & \multicolumn{2}{|c|}{$\begin{array}{l}\text { Children's surgery/ } \\
\text { Chirurgia dziecięca }\end{array}$} & \multicolumn{2}{|c|}{$\begin{array}{l}\text { General surgery/ } \\
\text { Chirurgia ogólna }\end{array}$} & \multicolumn{2}{|c|}{$\begin{array}{c}\text { Oncologic } \\
\text { surgery/Chirurgia } \\
\text { onkologiczna }\end{array}$} & \multicolumn{2}{|c|}{$\begin{array}{c}\text { Plastic surgery/ } \\
\text { Chirurgia } \\
\text { plastyczna }\end{array}$} & \multicolumn{2}{|c|}{$\begin{array}{l}\text { Dermatology/ } \\
\text { Dermatologia }\end{array}$} & \multicolumn{2}{|c|}{ Other/Inne } \\
\hline & No./Liczba & \%* & No./Liczba & \%* & No./Liczba & \%* & No./Liczba & \%* & No./Liczba & \%* & No./Liczba & \%* & No./Liczba & \%* \\
\hline D23 & $|353|$ & 83 & 855 & 71 & 3787 & 80 & 823 & 89 & 802 & 87 & 1169 & 75 & 4126 & 98 \\
\hline L03 & 16312 & 34 & 685 & 43 & 5799 & 46 & 43 & 49 & 14 & 50 & 0 & 0 & 1181 & 66 \\
\hline C44 & 9606 & 65 & 1 & 33 & 1837 & 98 & 2073 & 87 & 981 & 90 & 861 & 38 & 1912 & 96 \\
\hline D2I & 5962 & 93 & 519 & 87 & 2389 & 100 & 822 & 100 & 186 & 100 & 2 & 100 & 1825 & 93 \\
\hline L98 & 7991 & 42 & 1045 & 41 & 944 & 52 & 82 & 60 & 247 & 83 & 1 & 0 & $|46|$ & 67 \\
\hline $\mathrm{R} 22$ & 4624 & 42 & 23 & 23 & 28 & 82 & 17 & 100 & 18 & 100 & 6 & 50 & 2416 & 54 \\
\hline L02 & 1766 & 31 & 361 & 99 & 1028 & 99 & 8 & 100 & 4 & 100 & - & - & 354 & 99 \\
\hline L60 & 1715 & 36 & 645 & 67 & 262 & 47 & 0 & 0 & 0 & 0 & 2 & 5 & 131 & 90 \\
\hline 183 & 1315 & 43 & - & - & 769 & 76 & 3 & 100 & 0 & 0 & 0 & 0 & 125 & 80 \\
\hline L97 & 11469 & 6 & 0 & 0 & 749 & 17 & 2 & 40 & 9 & 47 & 0 & 0 & 99 & 4 \\
\hline Q82 & 1432 & 42 & 521 & 72 & 10 & 83 & 1 & 100 & 42 & 88 & 4 & I & 71 & 23 \\
\hline L08 & 2147 & 7 & 17 & 50 & 367 & 37 & 4 & 80 & 7 & 100 & 0 & 0 & 87 & 10 \\
\hline L89 & 4038 & 4 & 12 & 43 & 223 & 22 & 1 & 17 & 34 & 83 & 0 & 0 & 28 & 1 \\
\hline D04 & 307 & 81 & 1 & 100 & 55 & 71 & 32 & 82 & 2 & 67 & 134 & 92 & 37 & 90 \\
\hline A63 & 333 & 58 & 0 & 0 & 192 & 99 & 2 & 100 & - & - & 9 & 11 & 30 & 59 \\
\hline L9I & 1217 & 16 & 42 & 6 & 18 & 15 & - & - & 137 & 60 & 0 & 0 & 28 & 22 \\
\hline
\end{tabular}

the ALOS by ICD-10 code in dermatology and other wards. In the case of most of the conditions, the ALOS in the dermatology ward was shorter than in other units. The largest differences can be seen in pressure ulcers (L89), lower extremity ulcers (L97) and scleroderma (M34).

In the case of $4.4 \%$ of hospitalizations because of any skin condition analyzed in the study, they were followed by readmission to the same hospital within 30 days of discharge. The highest rate of readmission was determined with regard to hospitalization in rheumatology wards (14\%) followed by general medicine wards (10.6\%). Table 5 contains information about readmissions within 30 days of leaving the hospital. Treatment of psoriasis (L40) and systemic connective tissue disorders (M30, M31, M33) was associated with the highest readmission rates. In dermatology wards, the highest readmission rates were related to dermatopolymyositis (M33), pemphigus (L10) and mycosis fungoides (C84).

\section{DISCUSSION}

Data on inpatient dermatology is limited and originates mainly from single hospitals and dermatology łach chirurgicznych) oraz zapaleniem tkanki łącznej $(14 \%)$. Prawie połowę hospitalizacji na tych oddziałach stanowiły pobyty jednodniowe $(40,7 \%)$.

Pacjenci leczeni na oddziałach dermatologicznych byli starsi od pacjentów leczonych na oddziałach niedermatologicznych (odpowiednio 52,3 i 42,8 roku; $p<0,001$ ). Średnia długość pobytu w szpitalu wyniosła 5,1 dnia i była dłuższa w przypadku pacjentów przebywających na oddziałach niedermatologicznych $(p<0,001)$. W tabeli 4 zestawiono dane dotyczące średniej długości hospitalizacji według kodu ICD-10 na oddziałach dermatologicznych i pozostałych. Dla większości schorzeń średni czas pobytu na oddziale dermatologicznym był krótszy niż na pozostałych oddziałach. Największe różnice odnotowano w przypadku odleżyn (L89), owrzodzeń kończyn dolnych (L97) i twardziny układowej (M34).

W przypadku 4,4\% hospitalizacji spowodowanych jedną $\mathrm{z}$ analizowanych w badaniu chorób skóry w ciągu 30 dni od wypisu pacjenci byli ponownie przyjmowani do tego samego szpitala. Najwyższy wskaźnik ponownych przyjęć stwierdzono w przypadku hospitalizacji na oddziałach reumatologii (14\%) i medycyny ogólnej $(10,6 \%)$. Tabela 5 zawiera informacje o ponownych hospitalizacjach w czasie 30 dni od wypisu. Leczenie łuszczycy (L40) i układowych chorób tkanki łącznej (M30, 
Table 4. Length of stay by ICD- IO code which had a statistically significant test statistic in dermatology and other wards

Tabela 4. Czas hospitalizacji dla poszczególnych kodów ICD-I0, w przypadku których stwierdzono statystycznie znamienną statystykę testową dla oddziałów dermatologicznych i innych

\begin{tabular}{|c|c|c|c|c|c|}
\hline \multirow[t]{2}{*}{ ICD- 10} & \multirow{2}{*}{$\begin{array}{l}\text { No. of hospitalizations/ } \\
\text { Liczba hospitalizacji }\end{array}$} & \multicolumn{2}{|l|}{ ALOS* } & \multicolumn{2}{|l|}{ SD LOS** } \\
\hline & & Dermatology/Dermatologia & Other/Inne & Dermatology/Dermatologia & Other/Inne \\
\hline L03 & 22589 & 6.78 & 6.48 & 3.88 & 12.12 \\
\hline L40 & 20078 & 7.25 & 7.47 & 4.76 & 9.85 \\
\hline L50 & 14958 & 4.52 & 2.65 & 2.78 & 2.46 \\
\hline D23 & 13966 & 1.16 & 2.01 & 0.72 & 1.72 \\
\hline L97 & 13549 & 9.58 & 13.59 & 5.48 & 10.94 \\
\hline C44 & 11764 & 1.45 & 5.85 & 1.06 & 8.48 \\
\hline M35 & 11175 & 4.75 & 6.38 & 3.72 & 6.43 \\
\hline L98 & 9076 & 3.38 & 3.61 & 3.41 & 7.46 \\
\hline L89 & 8043 & 11.7 & 37.12 & 7.44 & 13.68 \\
\hline A46 & 6922 & 9.39 & 7.11 & 5.24 & 8.94 \\
\hline L08 & 6816 & 6.17 & 4.96 & 3.71 & 8.29 \\
\hline L20 & 6285 & 4.96 & 4.38 & 3.14 & 10.68 \\
\hline D21 & 6154 & 2.67 & 3.01 & 2.89 & 8.54 \\
\hline R22 & 5938 & 1.83 & 4.39 & 1.8 & 4.35 \\
\hline L02 & 5643 & 6.33 & 3.6 & 3.21 & 4.46 \\
\hline L30 & 5241 & 5.18 & 5.6 & 3.6 & 7.2 \\
\hline L27 & 5029 & 6.41 & 6.42 & 3.86 & 1.58 \\
\hline M32 & 4720 & 4.58 & 7.22 & 3.36 & 1.27 \\
\hline M3I & 4121 & 8.39 & 7.75 & 5.4 & 1.34 \\
\hline L23 & 3705 & 4.33 & 8.83 & 2.8 & 2.61 \\
\hline M34 & 3202 & 3.65 & 11.94 & 2.44 & 2.42 \\
\hline L60 & 2896 & 1.98 & 3.54 & 1.88 & 0.57 \\
\hline $\mathrm{T} 78$ & 2790 & 4.39 & 5.32 & 2.49 & 1.64 \\
\hline
\end{tabular}

*Average length of stay, **standard deviation for length of stay/*́rednia długość pobytu w szpitalu, **odchylenie standardowe długości pobytu.

departments in non-European countries. A study performed in Sao Paolo revealed that the most frequent admissions were due to eczema/dermatitis (17.5\%) and cutaneous infections (15.9\%) [2]. Similarly, in an Australian study, the most frequent reason for admission was dermatitis or eczema (37\%) and included patients who were admitted for the treatment of secondary infections [1]. The second most frequent reason for admission was for the management of lower extremity ulcers (12\%) [1]. Immunobullous disorders, infections, and drug reactions were the most common causes of inpatient admissions in Asian countries $[4,5]$. Alopecia areata, psoriatic erythroderma, acute urticaria and vasculitic purpura were the top four diagnoses ( $85 \%$ of hospitalizations) in Lebanon [3]. Some authors suggest that over the last few decades the characteristics of dermatology admissions in Europe have changed significantly [28]. In the UK, the most frequent diagnoses were psoriasis, chronic
M31, M33) wiązało się z najwyższym odsetkiem ponownych hospitalizacji. Na oddziałach dermatologicznych najwyższe wskaźniki ponownych przyjęć dotyczyły zapalenia skórno-mięśniowego (M33), pęcherzycy (L10) i ziarniniaka grzybiastego (C84).

\section{OMÓWIENIE}

Dane dotyczące hospitalizacji z powodów dermatologicznych są ograniczone i pochodzą głównie z pojedynczych szpitali i oddziałów dermatologicznych w krajach pozaeuropejskich. W badaniu przeprowadzonym w Sao Paolo wykazano, że do głównych dermatologicznych przyczyn hospitalizacji należą: wyprysk lub zapalenie skóry $(17,5 \%)$ i zakażenia skóry $(15,9 \%)$ [2]. Również w badaniu australijskim najczęstszą przyczyną przyjęć do szpitala było zapalenie skóry lub wyprysk (37\%). Badanie obejmowało pacjentów hospitalizowanych w celu leczenia zakażeń wtórnych [1]. Drugą najczęst- 
Table 5. Readmissions to the same hospital for any ICD- I 0 condition within 30 days of initial hospitalization - by ICD- I 0 code and ward type Tabela 5. Rehospitalizacje w tym samym szpitalu z powodu dowolnego kodu ICD- I 0 w ciągu 30 dni po zakończeniu pierwszej hospitalizacji - dla poszczególnych kodów ICD- 10 i typów oddziatów

\begin{tabular}{|c|c|c|c|c|c|c|c|c|c|c|c|c|c|c|}
\hline \multirow[b]{2}{*}{ 음 } & \multicolumn{2}{|c|}{ Total/Łącznie } & \multicolumn{2}{|c|}{$\begin{array}{l}\text { Dermatology/ } \\
\text { Dermatologia }\end{array}$} & \multicolumn{2}{|c|}{$\begin{array}{l}\text { Rheumatology/ } \\
\text { Reumatologia }\end{array}$} & \multicolumn{2}{|c|}{ Surgical/Chirurgia } & \multicolumn{2}{|c|}{$\begin{array}{c}\text { Internal medicine/ } \\
\text { Medycyna } \\
\text { wewnętrzna }\end{array}$} & \multicolumn{2}{|c|}{$\begin{array}{l}\text { Pediatric/ } \\
\text { Pediatria }\end{array}$} & \multicolumn{2}{|c|}{ Other/Inne } \\
\hline & 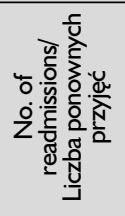 & 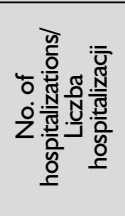 & 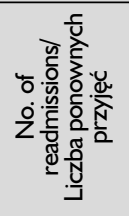 & $\stackrel{*}{\circ}$ & 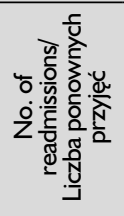 & क & 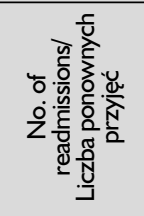 & 。̊ & 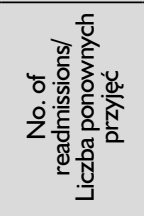 & $\stackrel{*}{\circ}$ & 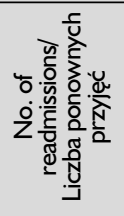 & 。o & 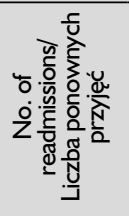 & $\stackrel{*}{\circ}$ \\
\hline L40 & 2146 & 20078 & 256 & 1.7 & 19 & 0.4 & - & - & I & 0.4 & - & - & I & 0.1 \\
\hline M3I & 1004 & 4121 & 10 & 4.4 & 337 & 20.1 & 2 & 25 & 163 & 24.7 & 17 & 12.3 & 226 & 15.9 \\
\hline A46 & 763 & 6922 & 61 & 4.7 & - & - & 3 & 1.5 & 3 & 0.8 & - & - & 585 & 11.7 \\
\hline L03 & 692 & 22589 & 3 & 1.6 & - & - & 305 & 2 & 4 & 1.8 & 3 & 2.4 & 9 & 0.1 \\
\hline L97 & 609 & 13549 & 114 & 2.6 & 1 & 16.7 & 126 & 2.6 & 21 & 1.7 & - & - & 74 & 2.4 \\
\hline M32 & 471 & 4720 & 17 & 5 & 304 & 10 & - & - & 24 & 5.3 & 20 & 13.1 & 91 & 12.4 \\
\hline C84 & 426 & 1089 & 28 & 7.4 & - & - & 1 & 6.7 & - & - & - & - & 58 & 8.4 \\
\hline M35 & 379 & 11175 & 12 & 4.2 & 247 & 3.2 & 2 & 11.8 & 51 & 3.1 & 24 & 4.6 & 20 & 2.1 \\
\hline C44 & 362 & 11764 & 67 & 2.9 & - & - & 136 & 2 & - & - & - & - & 78 & 3.1 \\
\hline L50 & 361 & 14958 & 46 & 2.2 & - & - & - & - & 26 & 1.5 & 13 & 0.3 & 11 & 0.2 \\
\hline M34 & 309 & 3202 & 29 & 3.7 & 238 & 11.5 & - & - & 21 & 10.6 & 8 & 20.5 & 7 & 6.3 \\
\hline M33 & 301 & 1717 & 28 & 19.7 & 167 & 15.7 & - & - & 7 & 6 & 23 & 20.5 & 25 & 9 \\
\hline L98 & 252 & 9076 & 5 & 2.1 & - & - & 15 & 1.1 & 3 & 4.1 & 4 & 1.4 & 2 & 0 \\
\hline L08 & 252 & 6816 & 31 & 3.1 & - & - & 103 & 2.1 & 3 & 1.9 & 3 & 0.8 & 31 & 1.2 \\
\hline L89 & 239 & 8043 & 1 & 1.8 & - & - & 48 & 4.1 & 35 & 1.5 & - & - & 8 & 0.2 \\
\hline L02 & 238 & 5643 & - & - & - & - & 27 & 1.6 & - & - & - & - & 2 & 0.1 \\
\hline L30 & 228 & 5241 & 34 & 1.1 & - & - & 2 & 1.9 & 4 & 1.5 & 2 & 2.6 & 1 & 0.1 \\
\hline M30 & 224 & 592 & - & - & 145 & 46.9 & - & - & 27 & 33.3 & - & - & 53 & 29.3 \\
\hline R22 & 168 & 5938 & - & - & - & - & 13 & 2.3 & - & - & - & - & 97 & 1.8 \\
\hline L20 & 163 & 6285 & 36 & 1.8 & - & - & - & - & 22 & 1.2 & 14 & 0.9 & 17 & 2 \\
\hline L94 & 132 & 1808 & 40 & 3.3 & 52 & 22.7 & - & - & - & - & 20 & 8.5 & 8 & 9.1 \\
\hline LIO & 114 & 775 & 65 & 8.8 & - & - & - & - & - & - & - & - & - & - \\
\hline L60 & 98 & 2896 & 1 & 2.4 & - & - & 19 & 1.2 & - & - & - & - & 2 & 0.2 \\
\hline 183 & 80 & 2067 & 2 & 1.4 & - & - & 21 & 1.8 & - & - & - & - & 1 & 0.1 \\
\hline D69 & 68 & 1613 & 3 & 1.2 & 2 & 6.2 & - & - & 3 & 3.9 & 21 & 2.2 & 12 & 3.4 \\
\hline B86 & 67 & 1064 & 7 & I & - & - & - & - & 1 & 6.2 & 1 & 1.9 & 1 & 0.4 \\
\hline $\mathrm{T} 78$ & 61 & 2790 & 4 & 2.1 & - & - & - & - & 21 & 2.1 & 6 & 1.3 & 7 & 0.6 \\
\hline
\end{tabular}

*No. of readmissions/No. of hospitalizations./*Liczba ponownych przyjęć/Liczba hospitalizacji.

ulcers and dermatitis, which represented more than $70 \%$ of inpatients in the 1970s, 1980s and 1990s [9, 10]. In fact, conditions such as psoriasis have shown a decreased level of admissions, potentially due to biological therapies [28]. Conversely, there has been an increase in the percentage of malignancy, possibly due to a longer life span [28]. In a Spanish study carried out in 2002, a high percentage of surgical szą przyczyną hospitalizacji były owrzodzenia kończyn dolnych (12\%) [1]. W krajach azjatyckich najczęstszymi przyczynami przyjęć do szpitala były autoimmunologiczne choroby pęcherzowe, zakażenia i reakcje na leki $[4,5]$. Natomiast w Libanie cztery główne rozpoznania ( $85 \%$ hospitalizacji) obejmowały łysienie plackowate, erytrodermię łuszczycową, ostrą pokrzywkę i plamicę [3]. Niektórzy autorzy podkreślają, że w ostatnich kilku dzie- 
dermatology inpatients (37\%) due to neoplasms was noted [11]. The next most frequent diagnoses were: infections $(15 \%)$, psoriasis $(10 \%)$, other skin diseases $(10 \%)$, dermatitis $(6 \%)$ and drug reactions (5\%) [11]. A similar profile of skin diseases leading to hospitalization was observed in this analysis. However, the main finding of the study was the high number of inpatients with dermatologic concerns in non-dermatology wards. Non-dermatologists managed $76 \%$ (75.8\%) of inpatients with cutaneous diseases in Poland. Skin tumors (D21, D23, D17, C44) and cellulitis (L03) were the most common reasons for hospitalization in 2018 ( 57.6 thousand admissions) and accounted for $23.5 \%$ of all hospital stays due to cutaneous conditions. They were managed most frequently by general surgeons $(67.1 \%)$. One-third of all hospitalizations in the analysis were surgical. Among the most common admissions for surgery were other disorders of the skin and subcutaneous tissue not elsewhere classified, localized swelling, masses and lumps on the skin and subcutaneous tissue, varicose veins of lower extremities with ulcer and inflammation, cutaneous abscesses, furuncle and carbuncle, nail disorders and other congenital malformations of the skin. Non-dermatology wards (mostly pediatric and general medicine wards) reported a significant proportion of emergency admissions due to cellulitis, urticaria, lower extremities ulcers, erysipelas, pressure ulcers, other skin and subcutaneous tissue disorders. Systemic connective tissue diseases were mostly treated by rheumatologists. The diseases most frequently treated by dermatologists were psoriasis (L40 - 35\%), dermatitis (L20, L27, L23, L30 - 24\%) and lower extremity ulcers (L97 - 11\%). The number of hospitalizations with regard to the aforementioned conditions was 1.3 times higher in dermatology wards than in non-dermatology ones. Therefore, the skin conditions that were most frequently reported by dermatologists differed considerably from those indicated by non-dermatologists. Many dermatology wards in Poland, especially regional hospitals in smaller towns, do not offer surgical procedures. Therefore, general practitioners are forced to refer patients who require operative treatment to surgical departments, regardless of the fact that the case is complex due to the surgery itself or because of patient-related factors. In contrast, dermatosurgery is an essential pillar of inpatient treatment, with up to $46 \%$ inpatient bed utilization in dermatology wards in western countries [11, 29]. Nonetheless, in 2012, the patients hospitalized with skin cancer in Germany were treated in non-dermatological departments in over half of the cases [30].

Currently, there is a worldwide trend aimed at reducing inpatient dermatology beds and increasing the number of non-dermatology physicians taking sięcioleciach charakterystyka przyjęć na oddziały dermatologiczne w Europie bardzo się zmieniła [28]. W Wielkiej Brytanii do najczęstszych rozpoznań należały: łuszczyca, przewlekłe owrzodzenia i zapalenie skóry (ponad $70 \%$ pacjentów szpitalnych w latach 70., 80. i 90. XX wieku) [9, 10]. W przypadku schorzeń takich jak łuszczyca odnotowano zmniejszenie liczby przyjęć, przypuszczalnie dzięki wprowadzeniu do lecznictwa terapii biologicznych [28]. Natomiast wzrósł odsetek zachorowań na nowotwory złośliwe, prawdopodobnie wskutek wydłużenia czasu życia [28]. Autorzy hiszpańskiego badania z 2002 roku stwierdzili wysoki odsetek pacjentów wymagających leczenia dermatochirurgicznego (37\%) z powodu nowotworów [11]. Kolejnymi najczęściej ustalanymi rozpoznaniami były: zakażenia (15\%), łuszczyca (10\%), inne choroby skóry (10\%), zapalenie skóry (6\%) i odczyny polekowe (5\%) [11]. Podobny profil chorób skóry prowadzących do hospitalizacji stwierdzono w niniejszym opracowaniu. Główną obserwacją, jaka wyłania się z badania, jest jednak duża liczba pacjentów hospitalizowanych z powodu schorzeń dermatologicznych na oddziałach niedermatologicznych. Odsetek pacjentów hospitalizowanych z powodu chorób skóry w Polsce, którymi zajmowali się lekarze innych specjalności niż dermatologia, wyniósł 76\% (75,8\%). Nowotwory skóry (D21, D23, D17, C44) i zapalenie tkanki łącznej (L03) były najczęstszymi przyczynami hospitalizacji w 2018 roku (57 000 przyjęć) i stanowiły 23,5\% wszystkich hospitalizacji z powodu chorób skóry. Ich leczeniem zajmowali się najczęściej chirurdzy ogólni (67,1\%). Jedna trzecia wszystkich hospitalizacji objętych analizą miała charakter chirurgiczny. Wśród najczęściej zgłaszanych chorób wymagających operacji były: inne choroby skóry i tkanki podskórnej niesklasyfikowane gdzie indziej, umiejscowiony obrzęk, guzek, guz skóry i tkanki podskórnej, żylaki kończyn dolnych z owrzodzeniami i stanami zapalnymi, ropnie skórne, czyraki (mnogie i gromadne), choroby paznokci oraz inne wrodzone wady rozwojowe skóry. Oddziały niedermatologiczne (głównie pediatryczne i ogólne) zgłaszały duży odsetek przyjęć w trybie pilnym z powodu zapalenia tkanki łącznej, pokrzywki, owrzodzeń kończyn dolnych, róży, odleżyn, innych chorób skóry i tkanki podskórnej. Układowe choroby tkanki łącznej były w większości przypadków leczone przez reumatologów. Do chorób najczęściej leczonych przez dermatologów należały: łuszczyca (L40 - 35\%), zapalenie skóry (L20, L27, L23, L30 - 24\%) oraz owrzodzenia kończyn dolnych (L97 - 11\%). Liczba hospitalizacji spowodowanych wymienionymi schorzeniami była 1,3 razy większa na oddziałach dermatologicznych niż na innych oddziałach. $Z$ tego powodu choroby skóry najczęściej zgłaszane przez dermatologów, znacząco różniły się od schorzeń wskazywanych przez lekarzy innych specjalności. Wiele oddziałów dermatologicznych w Polsce, zwłaszcza w szpitalach powiatowych w mniejszych miejscowościach, nie wykonuje świadczeń chirurgicznych. Z tego powodu lekarze ogólni są zmuszeni kierować pacjentów wymagających 
responsibility for inpatients, with the dermatologists acting as consultants. At the same time, recent papers have indicated an overall increase in the number of patients being hospitalized for skin problems and in healthcare cost associated with dermatologic inpatients [31-33]. In Poland, the vast majority of patients had common conditions. They were mostly resolved within a single admission. The ALOS was 6.74 days, which was significantly shorter compared to the aforementioned Australian and Brazilian studies (13 days and 10 days, respectively) $[1,2]$. Continually reduced ALOS, i.e. year by year (2003: 8.4; 2004: 7.3; 2005: 6.8; 2006: 6.3), was observed in the German study, parallel to an increase in dermatological hospital admissions and a growing importance of dermatological oncology [12]. According to the authors, a potential reason for this was the implementation of the diagnosis-related groups system in Germany, resulting in earlier discharges due to cost-cutting incentives [12]. Similarly, the introduction of the diagnosis-related groups system in Poland might have influenced the ALOS and the cases treated in an inpatient setting. According to the opinion of the author of this study, the high proportion of benign tumors and non-melanoma skin cancers might suggest that these patients may represent an inappropriate use of inpatient facilities. According to the recent findings, the rate of complications in major ambulatory surgery is zero or very low, even in patients of advanced age (over 85 years) [26, 27].

Although no data on dermatologic consultations were included, this study highlights the need to expand the dermatology resources for inpatient facilities. Dermatologic consultations for hospitalized patients constitute a growing workload in many countries. Based on literature data, the wards that most frequently requested consultations were mostly internal medicine, surgery and pediatrics, followed by hematology, oncology, neurology, obstetrics and gynecology [16-19, 24, 34-36]. Psychiatric patients were another group that demanded many dermatology consultations [23, 24,34]. Cardiology and infectious disease wards also played important roles in terms of demand for dermatological enquiries [23]. Infectious, drug-related, inflammatory skin conditions, chronic wounds and ulcers, as well as cutaneous neoplasms, accounted for the large majority of consultations [19, $23,36-38$ ]. In almost one-third of the cases, the dermatologist facilitated the management of the disease, which led to a shorter length of stay or initiation of treatment for a potentially severe dermatologic disease $[17,18,23]$. A quarter of the referrals concerned patients admitted through the emergency department with erythroderma [17]. Thirty-five percent of consultations were for patients aged over 75 years [20]. Immunocompromised patients accounted for more than leczenia operacyjnego na oddziały chirurgiczne, niezależnie od tego, czy dany przypadek jest skomplikowany ze względu na charakter zabiegu lub uwarunkowania związane z chorym. Dermatochirurgia stanowi filar leczenia szpitalnego, odpowiada za nawet $46 \%$ wykorzystania łóżek szpitalnych na oddziałach dermatologicznych w krajach zachodnich [11, 29]. Niemniej w 2012 roku pacjenci hospitalizowani z powodu raka skóry w Niemczech w ponad połowie przypadków byli leczeni na oddziałach niedermatologicznych [30].

Obecnie na świecie widoczny jest trend polegający na ograniczaniu w placówkach szpitalnych liczby łóżek dermatologicznych oraz zwiększaniu liczby lekarzy niedermatologów odpowiadających za leczenie hospitalizowanych pacjentów, przy czym dermatolodzy pełnią funkcję konsultantów. Jednocześnie w najnowszych publikowanych pracach sygnalizowany jest ogólny wzrost liczby pacjentów hospitalizowanych z powodu problemów skórnych oraz wzrost kosztów opieki zdrowotnej związanych z leczeniem szpitalnym pacjentów dermatologicznych [31-33]. W Polsce większość pacjentów była hospitalizowana z powodu typowych schorzeń. W przeważającej części do wyleczenia wystarczał jeden pobyt w szpitalu. Średni czas pobytu w szpitalu (average length of stay ALOS) wynosił 6,74 dnia. Jest to okres znamiennie krótszy niż we wspomnianych powyżej badaniach australijskich i brazylijskich (odpowiednio 13 dni i $10 \mathrm{dni}$ ) [1, 2]. Obniżanie się wartości ALOS rok do roku (2003: 8,4; 2004: 7,3; 2005: 6,8; 2006: 6,3) stwierdzono w badaniu niemieckim, a towarzyszyło mu zwiększenie liczby szpitalnych przyjęć dermatologicznych oraz wzrost znaczenia onkologii dermatologicznej [12]. Według autorów możliwą przyczyną tego trendu było wdrożenie w Niemczech systemu grup diagnostycznych, co doprowadziło do wcześniejszych wypisów pacjentów ze szpitala ze względu na zachęty do ograniczenia kosztów [12]. Podobnie w Polsce wprowadzenie systemu łączenia usług zdrowotnych w grupy diagnostyczne mogło mieć wpływ na ALOS i liczbę przypadków leczonych w warunkach szpitalnych. Według autorów niniejszej pracy wysoki odsetek guzów łagodnych i nieczerniakowych nowotworów skóry może wskazywać, że pacjenci z tej grupy są przykładem nieoptymalnego wykorzystywania zasobów szpitalnych. Według najnowszych ustaleń odsetek powikłań w przypadku dużych zabiegów chirurgicznych w warunkach ambulatoryjnych jest równy zeru lub bardzo niski, nawet u pacjentów w podeszłym wieku (powyżej 85 lat) [26, 27].

Mimo braku danych na temat konsultacji dermatologicznych niniejsze badanie wskazuje również na potrzebę zwiększania zaplecza dermatologicznego placówek lecznictwa zamkniętego. $W$ wielu krajach konsultacje dermatologiczne $\mathrm{u}$ hospitalizowanych pacjentów stanowią coraz większą część obciążenia pracą lekarzy. Z dostępnego piśmiennictwa wynika, że prośbę o konsultację dermatologiczną najczęściej zgłaszają oddziały chorób wewnętrznych, chirurgii i pediatrii, a następnie kolejno: hematologii, 
a third of all interdepartmental consultations [35]. Patients in nephrology, hematology and infectious disease departments required more follow-up visits and additional tests [35]. A quarter to one-third of the consulted patients required follow-up care after discharge $[3,17]$.

It is possible that the coding was rather lax, and incorrect assignment of ICD-10 codes to some conditions probably resulted in an inappropriate classification of some dermatological conditions, which may have concealed their true prevalence. Despite these limitations, the NHF database constitutes a large, nationally representative survey of inpatient care and represents one of the greatest data sources available for studies such as the one in question.

\section{CONCLUSIONS}

Treatment and management of skin diseases is an integral part of hospital care. Because of the changing conditions of medical care, the number of dermatology inpatient services is decreasing, while the number of patients managed by non-dermatologists is increasing. A higher number of dermatosurgeons and dermatologists as consultants within the hospital setting might contribute to ensuring better use of inpatient facilities.

\section{ACKNOWLEDGMENTS}

This paper has been prepared within the project Maps of Health Needs - Database of Systemic and Implementation Analyses. The project is cofinanced by the European Union from the European Social Fund under the Operational Programme Knowledge Education Development and it is being carried out by the Analyses and Strategies Department of the Polish Ministry of Health.

\section{CONFLICT OF INTEREST}

The authors declare no conflict of interest. onkologii, neurologii, ginekologii i położnictwa [16-19, 24, 34-36]. Duża potrzeba konsultacji dermatologicznych występuje wśród pacjentów oddziałów psychiatrycznych [23, 24, 34], a także oddziałów kardiologii i chorób zakaźnych [23]. Większość konsultacji dotyczy infekcyjnych, polekowych i zapalnych chorób skóry, przewlekłych ran i owrzodzeń oraz nowotworów skóry [19, 23, 36-38]. W niemal $1 / 3$ analizowanych przypadków dermatolog przyczynił się do skutecznego leczenia choroby, co doprowadziło do skrócenia pobytu w szpitalu lub podjęcia terapii schorzenia dermatologicznego o potencjalnie ciężkim przebiegu [17, 18, 23]. Jedna czwarta skierowań dotyczyła pacjentów z erytrodermią przyjętych do szpitala poprzez izbę przyjęć [17]. Trzydzieści pięć procent konsultacji dotyczyło pacjentów w wieku powyżej 75 lat [20]. Pacjenci z obniżoną odpornością stanowili ponad 1/3 wszystkich przypadków konsultacji międzyoddziałowych [35]. Pacjenci na oddziałach nefrologii, hematologii i chorób zakaźnych wymagali większej liczby wizyt kontrolnych i dodatkowych badań [35]. Od 1/4 do 1/3 konsultowanych chorych wymagało dalszej opieki lekarskiej po wypisie $[3,17]$.

Należy uwzględnić możliwość, że nadane kody ICD-10 nie były precyzyjne, a błędne przypisanie kodu prawdopodobnie skutkowało niewłaściwą klasyfikacją niektórych chorób dermatologicznych. To z kolei mogło maskować rzeczywistą częstość ich występowania. Pomimo tych ograniczeń baza danych NFZ umożliwia duże i reprezentatywne w skali kraju badanie opieki szpitalnej jako jedno z najobszerniejszych źródeł danych do tego typu analiz.

\section{WNIOSKI}

Leczenie pacjentów z chorobami skóry stanowi integralną część opieki szpitalnej. Ze względu na zmieniające się warunki funkcjonowania systemów opieki zdrowotnej zmniejsza się liczba szpitalnych świadczeń dermatologicznych, a zwiększa się liczba pacjentów leczonych przez lekarzy specjalności innych niż dermatologia. Zwiększenie liczby dermatochirurgów i dermatologów odgrywających rolę konsultantów szpitalnych może się przyczynić do optymalizacji zasobów szpitalnych.

\section{PODZIĘKOWANIA}

Praca powstała w ramach projektu „Mapy potrzeb zdrowotnych - Baza Analiz Systemowych i Wdrożeniowych". Projekt jest współfinansowany przez Unię Europejską z Europejskiego Funduszu Społecznego w ramach Programu Operacyjnego Wiedza Edukacja Rozwój i realizowany przez Departament Analiz i Strategii Ministerstwa Zdrowia.

\section{KONFLIKT INTERESÓW}

Autorzy nie zgłaszają konfliktu interesów. 


\section{References}

\section{Piśmiennictwo}

1. Bale J., Chee P.: Inpatient dermatology: pattern of admissions and patients' characteristics in an Australian hospital. Australas J Dermatol 2014, 55, 191-195.

2. de Paula Samorano-Lima L., Quitério L.M., Sanches J.A. Jr, Neto C.F.: Inpatient dermatology: profile of patients and characteristics of admissions to a tertiary dermatology inpatient unit in São Paulo, Brazil. Int J Dermatol 2014, 53, 685-691.

3. Maatouk I., Moutran R., Tomb R.: Hospitalization due to skin diseases at Hôtel-Dieu de France Hospital (Beirut), 1998-2007. J Med Liban 2012, 60, 99-102.

4. Sen A., Chowdhury S., Poddar I., Bandyopadhyay D.: Inpatient dermatology: characteristics of patients and admissions in a Tertiary Level Hospital in Eastern India. Indian J Dermatol 2016, 61, 561-564.

5. Parajuli S., Paudel U., Pokhrel D.B.: In patient dermatology: characteristics of patients and admissions in Tribhuvan University (TU) Teaching Hospital. Nepal J Dermatol Venereol Leprol 2013, 11, 59-63.

6. Raza N., Saleem J., Rashid Dar N., Malik N.A.: Why dermatology patients are hospitalized? A study from Pakistan. Acta Dermatovenerol Croat 2009, 17, 113-117.

7. Hasan S., Farshad F., Negin S., Parastoo D., Farzam G.: Patterns of admissions to a Referral Skin Hospital in Iran. Iran J Dermatol 2008, 11, 156-158.

8. Jessop S., McKenzie R., Milne J., Rapp S., Sobey G.: Pattern of admissions to a tertiary dermatology unit in South Africa. Int J Dermatol 2002, 41, 568-570.

9. Munro C.S., Lowe J.G., McLoone P., White M.I., Hunter J.A.: The value of in-patient dermatology: a survey of in-patients in Scotland and Northern England. Br J Dermatol 1999, 140, 474-479.

10. Ferguson J.A., Goldacre M.J., Newton J.N., Dawber R.P.: An epidemiological profile of in-patient workload in dermatology. Clin Exp Dermatol 1992, 17, 407-412.

11. García-Doval I., Feal C., Rosón E., de la Torre C., Abalde M.T., Flórez A., et al.: Inpatient dermatology: characteristics of patients and admissions in a Spanish hospital. J Eur Acad Dermatol Venereol 2002, 16, 334-338.

12. Hensen P., Beissert S., Bruckner-Tuderman L., Luger T.A., Roeder N., Müller M.L.: Introduction of diagnosis-related groups in Germany: evaluation of impact on in-patient care in a dermatological setting. Eur J Public Health 2008, 18, 85-91.

13. Ayyalaraju R.S., Finlay A.Y.: Inpatient dermatology. United Kingdom and United States similarities: moving with the times or being relegated to the back bench? Dermatol Clin 2000, 18, 397-404.

14. Kirsner R.S., Yang D.G., Kerdel F.A.: Dermatologic disease accounts for a large number of hospital admissions annually. J Am Acad Dermatol 1999, 41, 970-973.

15. Helbling I., Ferguson J.E., McKenna M.: Audit of admissions to dermatology beds in Greater Manchester. Clin Exp Dermatol 2002, 27, 519-522.

16. Prodanovich S., Kirsner R.S., Kerdel F.A.: Inpatient dermatology. A prescription for survival. Dermatol Clin 2001, 19, 593-602.

17. Alani A., Sadlier M., Uddin A., Hackett C., Ramsay B., Ahmad K.: An analysis of inpatient dermatologic consultations at University Hospital Limerick: inadequate infrastructure leads to acute skin failure. Ir J Med Sci 2017, 186, 305-307.

18. Özyurt S., Kelekçi K.H., Şeremet S., Özçelik S.: Analysis of inpatient dermatologic consultations. Actas Dermosifiliogr 2014, $105,799-800$

19. Conde Fernandes I., Velho G., Selores M.: Dermatology inpatient consultation in a Portuguese university hospital. Dermatology Online J 2012, 18, 16.

20. Maza A., Berbis J., Gaudy-Marqueste C., Morand J.J., Berbis P., Grob J.J., et al.: Evaluation of dermatology consultations in a prospective multicenter study involving a French teaching hospital. Ann Dermatol Venereol 2009, 136, 241-248.

21. Huang W., Chong W.S.: Patterns of inpatient dermatology referral and predictors of diagnostic accuracy in non-dermatologists in a Northern District hospital in Singapore. Int J Dermatol 2016, 55, 546-552.

22. Dantas L.D., Bakos L., Balbinot G., Drechsler C.E., Eidt L.M.: Prevalence of dermatoses in dermatologic evaluation requests from patients admitted to a tertiary hospital for 10 years. An Bras Dermatol 2015, 90, 762-764.

23. Mancusi S., Neto C.F.: Inpatient dermatological consultations in a university hospital. Clinics (Sao Paulo) 2010, 65, 851-855.

24. Davila M., Christenson L.J., Sontheimer R.D.: Epidemiology and outcomes of dermatology in-patient consultations in a Midwestern U.S. University Hospital. Dermatol Online J 2010, 16, 12.

25. Kroshinsky D., Cotliar J., Hughey L.C., Shinkai K., Fox L.P.: Association of dermatology consultation with accuracy of cutaneous disorder diagnoses in hospitalized patients: a multicenter analysis. JAMA Dermatol 2016, 152, 477-480.

26. Paradela S., Pita-Fernández S., Peña C., Fernández-Jorge B., García-Silva J., Mazaira M., et al.: Complications of ambulatory major dermatological surgery in patients older than 85 years. J Eur Acad Dermatol Venereol 2010, 24, 1207-1213.

27. Cortiñas-Sáenz M., Sáenz-Guirado S., Martínez-Díaz J.D.: Program for major outpatient surgery in dermatology. Actas Dermosifiliogr 2012, 103, 175-178.

28. Mashayekhi S., Hajhosseiny R.: Dermatology, an interdisciplinary approach between community and hospital care. JRSM Short Rep 2013, 4, 1-4.

29. Kunte C., Pfützner W., Kerschenlohr K., Konz B.: Dermatology - a surgical discipline - as exemplified by surgical procedures at the Hospital of Munich Thalkirchner Strasse. J Dtsch Dermatol Ges 2008, 6, 555-561.

30. Augustin M., Anastasiadou Z., Schaarschmidt M.L., Krensel M., Schäfer I., Reusch M.: Care for skin cancer in Germany: provision and providers. Hautarzt 2016, 67, 544-548.

31. Hu L., Haynes H., Ferrazza D., Kupper T., Qureshi A.: Impact of specialist consultations on inpatient admissions for dermatology-specific and related DRGs. J Gen Intern Med 2013, 28, 1477-1482.

32. Martínez-Morán C., Borbujo J.: Hospitalization of dermatologic patients: why, when, and where? Actas Dermosifiliogr 2017, 108, 395-399.

33. Noe M.H., Rosenbach M.: Inpatient dermatologists-crucial for the management of skin diseases in hospitalized patients. JAMA Dermatol 2018, 154, 524-525. 
34. Peñate Y., Guillermo N., Melwani P., Martel R., Borrego L.: Dermatologists in hospital wards: an 8-year study of dermatology consultations. Dermatology 2009, 219, 225-231.

35. Lorente-Lavirgen A.I., Bernabeu-Wittel J., Pulpillo-Ruiz Á., de la Torre-García J.M., Conejo-Mir J.: Inpatient dermatology consultation in a Spanish tertiary care hospital: a prospective cohort study. Actas Dermosifiliogr 2013, 104, 148-155.

36. Storan E.R., McEvoy M.T., Wetter D.A., El-Azhary R.A., Camilleri M.J., Bridges A.G., et al.: Experience of a year of adult hospital dermatology consultations. Int J Dermatol 2015, 54, 1150-1156.

37. Connolly D.M., Silverstein D.I.: Dermatology consultations in a tertiary care hospital: a retrospective study of 243 cases. Dermatol Online J 2015, 21, 13030/qt47m711t2.

38. Lambert A., Delaporte E., Lok C., Froment L., Bailly L., Denoeux J.P., et al.: Skin diseases observed in the dermatology departments of three French university teaching hospitals. Ann Dermatol Venereol 2006, 133, 657-656.

Received: 2.10 .2020

Accepted: 10.02 .2021

Otrzymano: $2.10 .2020 \mathrm{r}$.

Zaakceptowano: $10.02 .2021 \mathrm{r}$.

How to cite this article

Lis-Swiety A., Niewiedzioł M., Ciulkin K., Niemczyk W., Paciorek S., Więckowska B., Droździkowska A.: Inpatient care for patients with skin conditions in Poland - hospitalization and patient characteristics. Dermatol Rev/Przegl Dermatol 2021, 108, 1-15. DOI: https://doi.org/10.5114/dr.2021.105888. 